\title{
Effect of Mg Content and Heat Treatment on the Mechanical Properties of Low Pressure Die-Cast 380 Alloy
}

\author{
S. Morin, ${ }^{1}$ E. M. Elgallad, ${ }^{1}$ H. W. Doty, ${ }^{2}$ S. Valtierra, ${ }^{3}$ and F. H. Samuel ${ }^{1}$ \\ ${ }^{1}$ Université du Québec à Chicoutimi, Saguenay, QC, Canada \\ ${ }^{2}$ General Motors, Materials Engineering, 823 Joslyn Avenue, Pontiac, MI 48340, USA \\ ${ }^{3}$ Corporativo Nemak, S.A. de C.V., P.O. Box 100, 66221 Garza Garcia, NL, Mexico \\ Correspondence should be addressed to F. H. Samuel; fhsamuel@uqac.ca
}

Received 5 June 2016; Revised 3 September 2016; Accepted 18 September 2016

Academic Editor: Akihiko Kimura

Copyright (C) 2016 S. Morin et al. This is an open access article distributed under the Creative Commons Attribution License, which permits unrestricted use, distribution, and reproduction in any medium, provided the original work is properly cited.

\begin{abstract}
The present study was carried out on a 380 alloy containing $9.13 \% \mathrm{Si}, 3.22 \% \mathrm{Cu}, 1.01 \% \mathrm{Fe}, 0.06 \% \mathrm{Mg}, 0.16 \% \mathrm{Mn}$, and $2.28 \% \mathrm{Zn}$. The magnesium level was increased to 0.3 and $0.55 \%$, by adding pure $\mathrm{Mg}$ to the melt. Tensile and fatigue samples were produced using low pressure die casting. The results show that the average dendrite arm spacing was about $6 \mu \mathrm{m}$. Increasing the amount of $\mathrm{Mg}$ from $0.06 \%$ to $0.55 \%$ increased the volume fraction of $\pi-\mathrm{Al}_{8} \mathrm{Mg}_{3} \mathrm{FeSi}_{6}$ and $\mathrm{Q}-\mathrm{Al}_{5} \mathrm{Cu}_{2} \mathrm{Mg}_{8} \mathrm{Si}_{6}$ phases from $0.8 \%$ to $1.7 \%$. Following solutionizing at $490^{\circ} \mathrm{C}$ for $8 \mathrm{~h}$, the maximum ultimate tensile strength was obtained from alloys containing $0.3 \% \mathrm{Mg}$. Further increases in $\mathrm{Mg}$ content resulted in an increase in the amount of insoluble intermetallics and, hence, low tensile strength. Aging at $155^{\circ} \mathrm{C}$ for times up to $25 \mathrm{~h}$ resulted in a linear increase in the alloy strength regardless of the amount of added $\mathrm{Mg}$. Aging at $220^{\circ} \mathrm{C}$, however, revealed multiple peaks corresponding to the precipitation of various phases. A good relation between the applied force and the number of cycles prior to failure was established. The alloy containing $0.3 \% \mathrm{Mg}$ produced the best fatigue resistance. The effect of porosity was more pronounced on the fatigue samples than on the tensile bars.
\end{abstract}

\section{Introduction}

Fatigue is considered the most common mechanism by which engineering components fail and accounts for at least $90 \%$ of all service failures due to mechanical causes. Failures occurring under conditions of dynamic loading are termed fatigue failure. Fatigue failure is particularly insidious as it occurs without any obvious warning, resulting in sudden or catastrophic failures $[1,2]$. Fatigue is defined as the process of progressive localized permanent structural change occurring in a material subjected to conditions that produce fluctuating stresses and strains at some point that may culminate in cracks or complete fracture after a sufficient number of fluctuations [3]. Three factors are necessary for fatigue failure: (i) a maximum tensile stress of sufficiently high value, (ii) a large variation or fluctuation in the applied stress, and (iii) a sufficiently large number of cycles of the applied stress. The fatigue process itself can be divided into four stages: (i) cyclic hardening/softening, (ii) crack nucleation, (iii) crack propagation, and (iv) overload (fracture). At low amplitudes, the nucleation stage can occupy the majority of the fatigue life, while, at high amplitudes, nucleation is accomplished within a small fraction of the fatigue life [4].

A fluctuating stress cycle is made up of two components, a mean stress, $\sigma_{m}$, and an alternating stress, $\sigma_{a}$. Taking into consideration the maximum stress, $\sigma_{\max }$, the minimum stress, $\sigma_{\min }$, and the stress range $\sigma_{r}$ (defined as $\sigma_{\max }-\sigma_{\min }$ ), $\sigma_{m}$ and $\sigma_{a}$ are defined as follows:

Mean stress:

$$
\sigma_{m}=\frac{\sigma_{\max }+\sigma_{\min }}{2}
$$

Alternating stress:

$$
\sigma_{a}=\frac{\sigma_{\max }-\sigma_{\min }}{2}
$$

The general factors affecting the fatigue life of cast aluminum alloys include the stress amplitude, mean stress, stress 
concentration, surface effects (surface roughness, stress raiser at the surface, and surface hardening), size and design of the component, effects of environment (corrosion, oxidation, fretting, and temperature), thermal stresses, and the effect of metallurgical variables [5].

The metallurgical factors that are taken into account, in order to ensure optimum fatigue performance, include heat treatment, alloying additions, stacking fault energy, grain size, and inclusion and porosity content. Ammar et al. [610] studied the effect of porosity on fatigue strength of AlSi alloys. The porosity levels were varied by adding hydrogen gas to the alloy melt. The pores have a negative effect on the fatigue strength in that as the porosity volume fraction in the specimen increases, the fatigue life decreases. Using scanning electron microscopy to examine the fatigue fracture surface, it was found that the fatigue crack is often nucleated at pores. They also observed that the effect of inclusions on porosity formation depends not only on the number, size, and spatial distribution but also on the nature, that is, type and shape of the inclusions.

The application of chilling and insulation also affect the solidification time and, consequently, the casting soundness. The appropriate location and sizing of risers are thus very important in the production of high-quality castings. Sigworth and Caceres [11] reported that, in directionally solidified castings, a significant increase in the amount of dispersed microporosity is observed when moving from a location near the chill to a location near the riser. This can create problems in alloys having extremely long freezing range in that the riser section may become mushy and stiff long before the interior of the casting freezes completely.

On the macroscopic scale, a fatigue failure can usually be recognized from the appearance of the fracture surface, which consists of two main regions: (i) a smooth region, due to the rubbing action as the crack propagates through the section, and (ii) a rough region, where the component has failed in a ductile manner when the cross-section is no longer able to carry the applied load. The progress of the fracture is indicated by a series of rings, or "beach marks" progressing inward from the point of initiation of the failure [12]. Fracture surfaces are often called typical fatigue failures because they exhibit the following common features [13]: (i) a distinct crack nucleation site (or sites), (ii) beach marks indicative of crack growth, and (iii) a distinct final fracture region.

Gundlach et al. [14] studied the effects of microstructural variables such as solidification rate, dendrite arm spacing (DAS), level of porosity, eutectic silicon modification, and Ferich intermetallic phases on the thermal fatigue properties of Al-Si alloys. They found that when the increase in porosity content was accompanied by an increase in DAS, thermal fatigue life dropped by $66 \%$, probably as a result of an increase in the size of microporosity voids. Large shrinkage pores promote the initiation of fatigue cracks, leading to premature failure of the samples with high dispersion of data due to variability in the critical pore size. The damaging effect of a pore is related to local stress concentration [15].

The present study was undertaken to investigate the effect of $\mathrm{Mg}$ content and heat treatment on the tensile properties

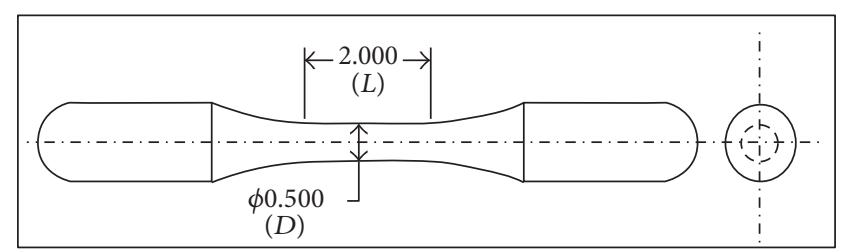

(a)

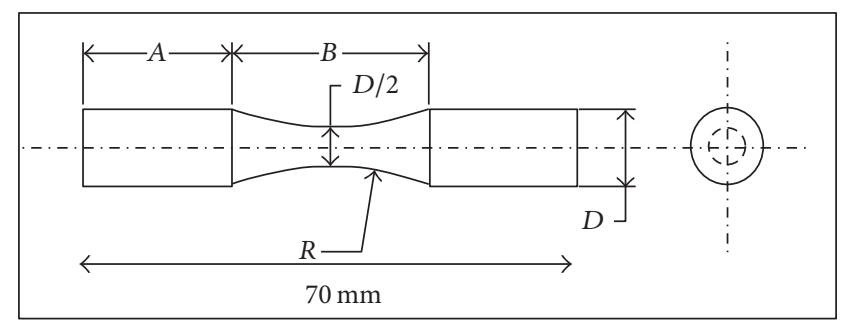

(b)

Figure 1: (a) Dimensions of the tensile sample in inch. (b) Dimensions of the fatigue sample, $R=6.4 \mathrm{~mm}$.

TABLE 1: Chemical composition of the as-received 380 alloy ingots.

\begin{tabular}{ccccccccr}
\hline & \multicolumn{8}{c}{ Element (wt\%) } \\
& $\mathrm{Si}$ & $\mathrm{Cu}$ & $\mathrm{Fe}$ & $\mathrm{Mg}$ & $\mathrm{Mn}$ & $\mathrm{Zn}$ & $\mathrm{Ti}$ & $\mathrm{Al}$ \\
\hline $\mathrm{A} 380.1$ & 9.18 & 3.22 & 1.01 & 0.06 & 0.15 & 2.29 & 0.02 & Bal. \\
\hline
\end{tabular}

and fatigue life of a 380 alloy produced by low pressure die casting.

\section{Experimental Procedure}

Table 1 lists the chemical composition of the as-received alloy. All alloys investigated were melted using an electric induction furnace. The melting temperature was maintained at $730^{\circ} \pm 5^{\circ} \mathrm{C}$. Measured amounts of pure $\mathrm{Mg}$ were added using a perforated bell-like graphite rod. The molten metal was degassed using pure dry argon injected into the molten metal $\left(30 \mathrm{ft}^{3} / \mathrm{h}\right)$ by a rotary degassing impeller made of graphite. The degassing time/speed was kept constant at $30 \mathrm{~min} / 150 \mathrm{rpm}$ in order to obtain a lower hydrogen level of $\sim 0.1 \mathrm{~mL} / 100 \mathrm{~g}$ in the melt. All the molten alloys were grain-refined before degassing using the Al-5 wt $\%$ Ti- 1 wt $\%$ B master alloy. The molten metal was thereafter cast into small ingots (1 kg).

The small ingots were thereafter remelted in the furnace attached to the low pressure permeant mold machine (LPPM) to cast tensile and fatigue samples. The samples obtained were net shape test samples and not subsequently subjected to any further machining process. Figure 1 shows the dimensions of the tensile and fatigue samples used in the present study according to the ASTM B 557 and E466 standards, respectively. The work was carried out at the Gibb low pressure die casting laboratory in Kentucky, Illinois. Samples for chemical analysis were also extracted simultaneously for each melt casting. The chemical compositions representing the average 
TABLE 2: Alloy codes and Mg concentration.

\begin{tabular}{lc}
\hline Alloy code & $\mathrm{Mg}(\mathrm{wt} . \%)$ \\
\hline DCM0 & 0.06 \\
DCM3 & 0.30 \\
DCM5 & 0.55 \\
\hline
\end{tabular}

of three spectrometric analyses for all the alloys investigated are listed in Table 2.

All samples were solution heat treated (SHT) at $490^{\circ} \mathrm{C}$ for $8 \mathrm{~h}$, in a Blue $\mathrm{M}$ forced-air electric furnace, followed by quenching in warm water at $60^{\circ} \mathrm{C}$. The quenched samples were aged at $155^{\circ} \mathrm{C}$ and $220^{\circ} \mathrm{C}$ for times up to $25 \mathrm{~h}$. The tensile test bars were pulled to fracture at room temperature at a strain rate of $4 \times 10^{-4} \mathrm{~s}^{-1}$, using a servohydraulic MTS mechanical testing machine. An extensometer (with a $25 \mathrm{~mm}$ range) was attached to the test bar to measure percentage elongation as the load was applied.

The tensile properties, namely, yield stress (YS) at a $0.2 \%$ offset strain, ultimate tensile strength (UTS), and fracture elongation (\%El), were derived from the data-acquisition and data-treatment systems of the software. The tensile properties of each alloy condition were represented by the average $\% \mathrm{El}$, YS, and UTS values which were calculated over the values obtained from the five tensile test bars assigned to that condition. Fatigue samples were tested using a rotatingbending type machine. In each case, at least five bars were tested and average was plotted.

Measurement of the secondary dendrite arm spacing (SDAS) was carried out for all alloys using an optical microscope and image-analysis system. The line intercept method was used to calculate the average secondary dendrite arm spacing. Ten fields were examined for each sample, each field containing at least three lines which intercept the secondary dendrite arms. The samples were prepared for SDAS measurement using the same procedures applied for preparing the samples for eutectic silicon particle characterization.

The intermetallic phases were identified by means of an electron probe microanalyzer (EPMA) in conjunction with a wavelength dispersive spectrometer (WDS), using a JEOL JXA-8900L WD/ED combined microanalyzer operating at $20 \mathrm{kV}$ and $30 \mathrm{nA}$ with an electron beam size of $\sim 2 \mu \mathrm{m}$. The surface fraction of the intermetallic phases was quantified using a JEOL JXA-8900L model electron probe microanalyzer with a special built-in software based on phase brightness where the brightness of each phase is a function of its average atomic number.

The fracture surfaces of the fatigue specimens after the test were examined and analysed by a Zeiss scanning electron microscopy (SEM) to monitor the crack propagation path and the fracture mode. Samples were cut approximately a quarter inch from the fracture surface of the upper part which was used for fractographic examination. Extra care was taken during the cutting to avoid contamination of the fracture surface.

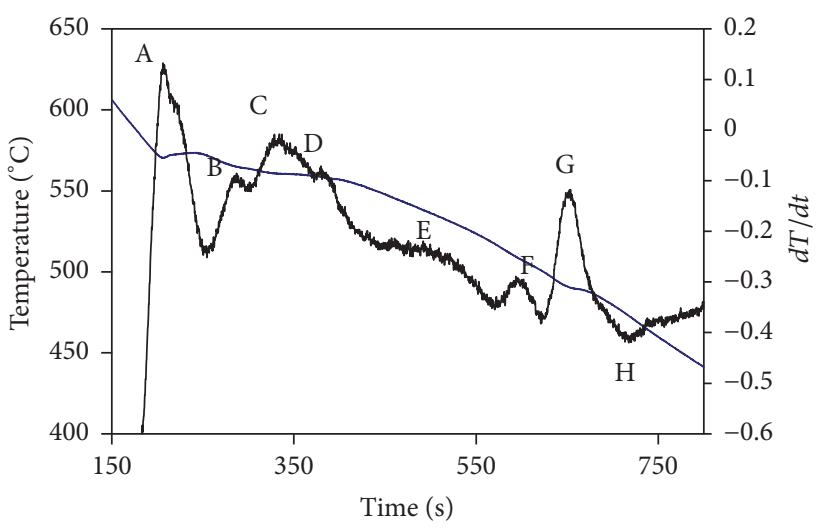

FIGURE 2: Solidification curve and its 1st derivative obtained from DCM5 alloy.

\section{Results and Discussion}

3.1. Microstructural Analysis. In order to arrive at a clear understanding of the effect of $\mathrm{Mg}$ content on the alloy microstructure, thermal analysis was carried out, as mentioned elsewhere [16]. Figure 2 is a typical solidification curve obtained from the 380 alloy containing $0.55 \% \mathrm{Mg}$ (DCM5). Details of the observed reaction are listed in Table 3 [17]. As can be seen in Figure 2, Q phase in high Mg-containing alloys precedes the formation of $\mathrm{Al}_{2} \mathrm{Cu}$ phase. Similar observation was made by Samuel et al. [18] when the $\mathrm{Mg}$ in 319 alloy exceeded $0.3 \%$. Figure 3 depicts the main phases precipitated in DCM5 alloy. As can be seen, the Q phase precipitates in two distinct forms.

Due to the high solidification rate associated with the LPDC process, the obtained structure is ultrafine (Figure 4(b)) compared to that produced under nearequilibrium conditions (Figure 4(a)). Moreover, the increase in the $\mathrm{Mg}$ content resulted in lowering the precipitation temperature of the $\mathrm{Al}_{2} \mathrm{Cu}$ phase to approximately $491^{\circ} \mathrm{C}$ (Figure 2). Thus, solutionizing the DCM5 alloy at $490^{\circ} \mathrm{C}$ for $8 \mathrm{~h}$ would cause incipient melting of the $\mathrm{Cu}$-containing phase (Figure 5(b), arrowed) leading to drop in the alloy mechanical properties. In addition, Figure 5(c) reveals the presence of a large amount of undissolved $\mathrm{Al}_{2} \mathrm{Cu}$ which would lead to drop in the alloy mechanical properties. Table 4 lists the volume fraction of porosity in the three studied alloys before and after SHT. As can be seen, the amount of porosity increased with the increase in the Mg level, following SHT.

3.2. Tensile and Fatigue Properties. Figure 6 presents the tensile properties obtained from the three studied alloys following $\mathrm{T} 6\left(155^{\circ} \mathrm{C}\right)$ treatments. Increasing the aging time at $155^{\circ} \mathrm{C}$ seems to increase the alloy UTS and YS linearly, with a linear reduction in the ductility regardless of the $\mathrm{Mg}$ concentration. The reported results may be interpreted in terms of the precipitation of GP zones $[19,20]$. The work of Apelian et al. [21] on the fundamental aspects of heat treatment of Al-Si$\mathrm{Mg}$ alloys shows that, in order to maximize the dissolution of $\mathrm{Mg}$ and $\mathrm{Si}$ in the aluminum matrix, the temperature of SHT should be very close to the eutectic temperature. The 

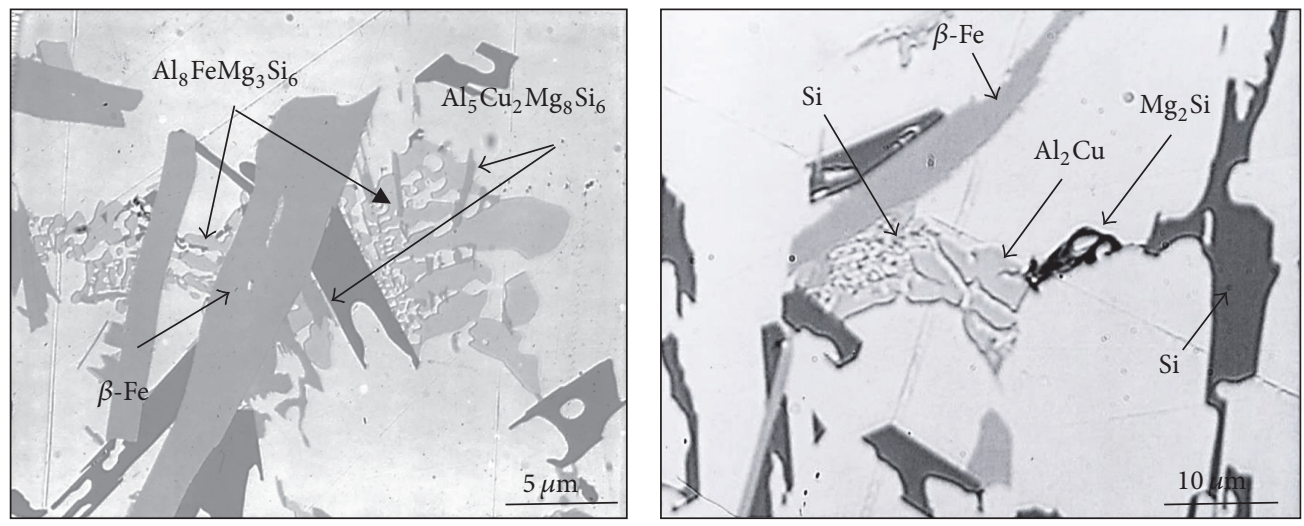

FIGURE 3: Microstructure of the as-cast DCM5 alloy (thermal analysis) showing different phases. The average dendrite arm spacing is $85 \mu \mathrm{m}$.

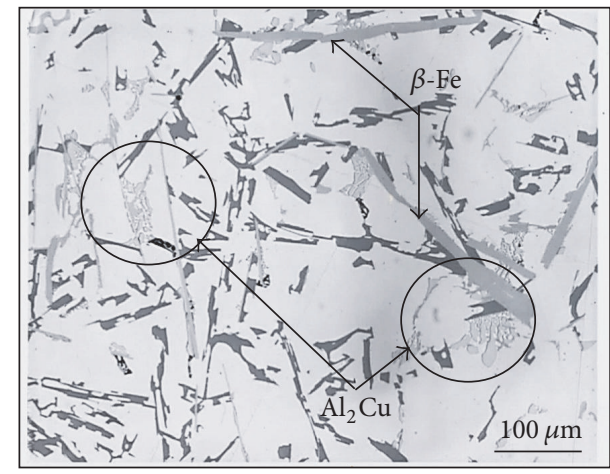

(a)

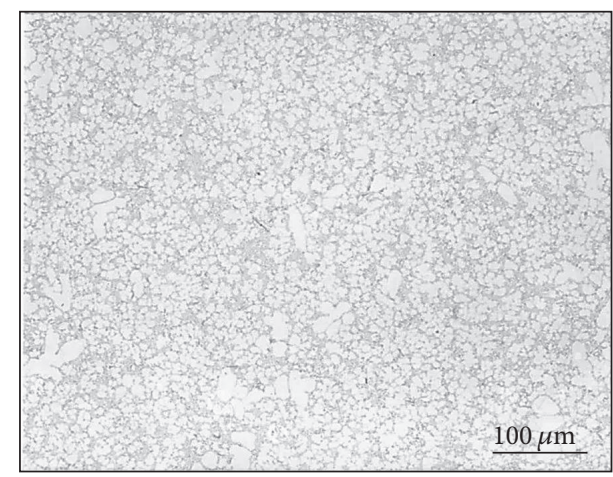

(b)

FIGURE 4: Microstructure obtained from DCM5 alloy: (a) DAS $\sim 85 \mu \mathrm{m}$ and (b) DAS $\sim 6 \mu \mathrm{m}$ (LPDC).

TABLE 3: Solidification reactions obtained from the three studied alloys.

\begin{tabular}{|c|c|c|c|c|}
\hline \multirow{2}{*}{ Mark } & \multicolumn{3}{|c|}{ Measured temperature $\left({ }^{\circ} \mathrm{C}\right)$} & \multirow{2}{*}{ Reaction } \\
\hline & $0.06 \% \mathrm{Mg}$ & $0.3 \% \mathrm{Mg}$ & $0.55 \% \mathrm{Mg}$ & \\
\hline $\mathrm{A}$ & 572.7 & 572.9 & 570.4 & Formation of $\alpha$-Al phase \\
\hline B & 567.7 & 567.7 & 564.6 & Precipitation of $\beta-\mathrm{Al}_{5} \mathrm{SiFe}$ phase \\
\hline $\mathrm{C}$ & 563.8 & 561.9 & 560.6 & Formation of Al-Si eutectic \\
\hline $\mathrm{D}$ & 536.0 & 539.5 & 537.6 & Transformation phase $\beta$ - $\mathrm{Fe} \rightarrow \mathrm{Al}_{8} \mathrm{Mg}_{3} \mathrm{FeSi}_{6}$ \\
\hline $\mathrm{E}$ & 513.8 & 508.8 & 508.3 & Precipitation of $\mathrm{Mg}_{2} \mathrm{Si}$ phase \\
\hline $\mathrm{F}$ & 499.5 & 489.5 & 490.1 & Precipitation of $\mathrm{Al}_{2} \mathrm{Cu}$ eutectic \\
\hline G & 485.0 & 486.0 & 488.0 & Formation of $\mathrm{Q}-\mathrm{Al}_{5} \mathrm{Mg}_{8} \mathrm{Cu}_{2} \mathrm{Si}_{6}{ }^{*}$ phase \\
\hline $\mathrm{H}$ & 490.0 & 480.0 & 480.0 & End of solidification \\
\hline
\end{tabular}

${ }^{*}$ In the case of DCM5, Q phase precipitates before $\mathrm{Al}_{2} \mathrm{Cu}$ reaction [18].

fact that the present alloys contain about $3.2 \% \mathrm{Cu}$ limits the maximum solutionizing temperature to avoid the occurrence of incipient melting [22] and hence the maximum amount of $\mathrm{Mg}$ that could be added to the 380 alloy. The hardening in 380 alloys is caused by the precipitation of $\mathrm{Mg}_{2} \mathrm{Si}, \mathrm{CuAl}_{2}$, and $\mathrm{Al}_{2} \mathrm{CuMg}$. In the present work, $0.3 \% \mathrm{Mg}$ is found to be the optimum concentration. Thus the final strength is determined by the simultaneous precipitation of these three phases and their volume fraction, particle size, and their coherency with the aluminum matrix [23,24]. Figure 7 shows the retention of a large quantity of undissolved $\mathrm{Cu}$-containing phases in DCM5 alloy following SHT and hence the observed weak hardening in this alloy compared to DCM3.

Figure 8 exhibits the tensile properties of the present alloys following $\mathrm{T} 7\left(220^{\circ} \mathrm{C}\right)$ treatment. In this case, although the UTS remained more or less constant during the entire aging time, the YS revealed multiple peaks in DCM3 and DCM5 alloys, depending on the precipitating phase. The 


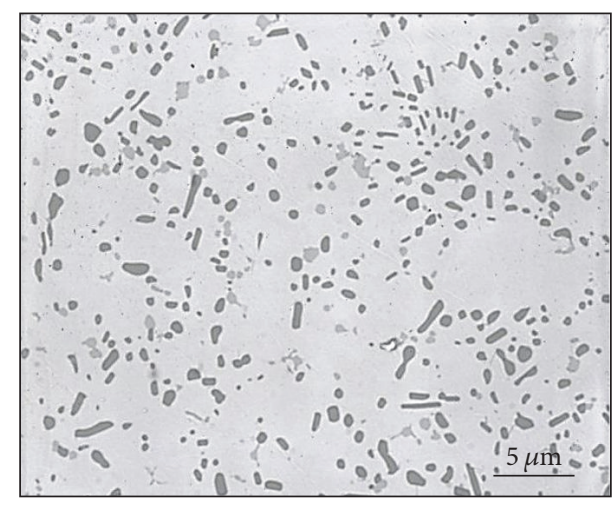

(a)

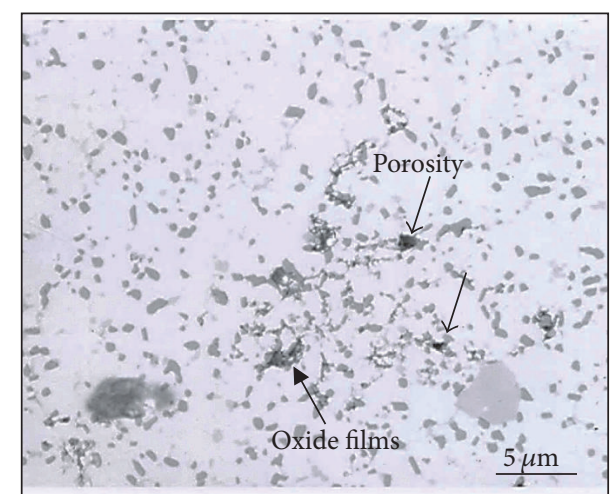

(b)

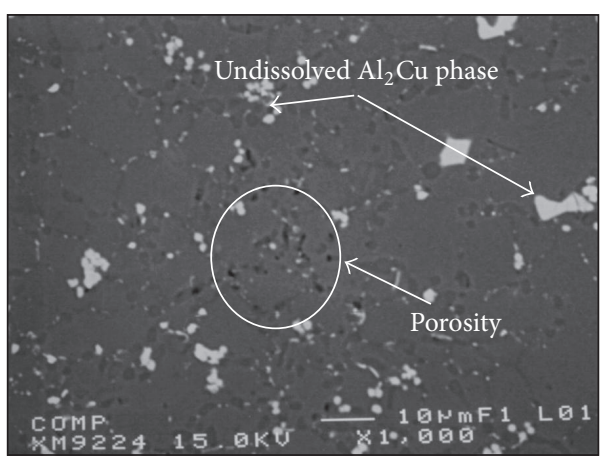

(c)

FIGURE 5: Microstructure of (a) 0.06 and (b and c) $0.55 \% \mathrm{Mg}$-containing alloys following SHT.

TABLE 4: Porosity volume fraction (\%) measured in the three studied alloys.

\begin{tabular}{lcc}
\hline Alloy code & \multicolumn{2}{c}{ Condition } \\
& After casting & After SHT \\
\hline DCM0 & 0.015 & 0.50 \\
DCM3 & 0.018 & 0.80 \\
DCM5 & 0.018 & 1.20 \\
\hline
\end{tabular}

first peak was observed after $5 \mathrm{~h}$ whereas the second one took place after $20 \mathrm{~h}$. The YS value after $20 \mathrm{~h}$ is relatively smaller than that obtained after $5 \mathrm{~h}$. Similar observations have been reported by Andrade-Gonzalez et al. [25-28] on the aging behaviour of $\mathrm{Mg}$-containing 319 alloy. Lumly et al. [19] reported that alloys $360(\mathrm{Al}-9.5 \mathrm{Si}-0.5 \mathrm{Mg})$ and 380 (Al-8.5Si$3.5 \mathrm{Cu}$ ) have shown strong response to age hardening. For T6 tempers, increases in $0.2 \%$ proof stress of $80 \%$ for the 360 alloy and $115 \%$ for the 380 alloy have been obtained compared with as-cast values. Based on these observations, Figure 9 represents schematically the expected precipitate behaviour during aging at $220^{\circ} \mathrm{C}$.

According to different references, the applied stress should exceed the YS level [29] since

$$
\begin{gathered}
\sigma=\frac{32 * M}{\pi * D^{3}} \\
\text { or } M=0,0982 * \sigma * D,
\end{gathered}
$$

where $M$ is the applied moment, $D$ is the sample diameter, and $\sigma$ is the applied stress (about $60 \%$ of UTS value). In the present study, the bean was rotating at $10000 \mathrm{rpm}$. The dependence of number of fatigue cycles on the amount of $\mathrm{Mg}$ of as-cast alloys is illustrated in Figure 10. From this figure it is evident that increasing the $\mathrm{Mg}$ content beyond $0.3 \%$ has no significant effect on the number of cycles prior to failure. Thus, the more the alloy is ductile, the more the number of fatigue cycles is required before fracture as inferred from Figure 11 .

In the present section, for DCM3 and DCM5 alloys, two aging conditions were considered $\left(10\right.$ and $20 \mathrm{~h}$ at $220^{\circ} \mathrm{C}$ ). Due to the presence of a marked amount of porosity caused by incipient melting, the applied forces were selected in the elastic range $(85,110$, and $130 \mathrm{MPa})$. Increase in the $\mathrm{Mg}$ content from $0.3 \%$ to $0.55 \%$ has a relatively slight influence on the alloy performance. Figure 12(b) reveals how the curves are skewed to the $Y$-axis compared to the curves in Figure 12(a). Also, DCM5 alloy revealed somewhat lesser number of cycles compared to DCM3 under the same applied stress. It should be noted that, in all case, none of the alloys has shown an endurance limit where the increase in the applied stress is associated with the change in the number of cycles.

3.3. Fractography. Figure 13(a) shows the fracture surface of fatigue tested alloys following solidification. When the amount of $\mathrm{Mg}$ is as high as $0.3 \%$, the fracture surface of the as-cast sample is characterized by the presence of a crack 


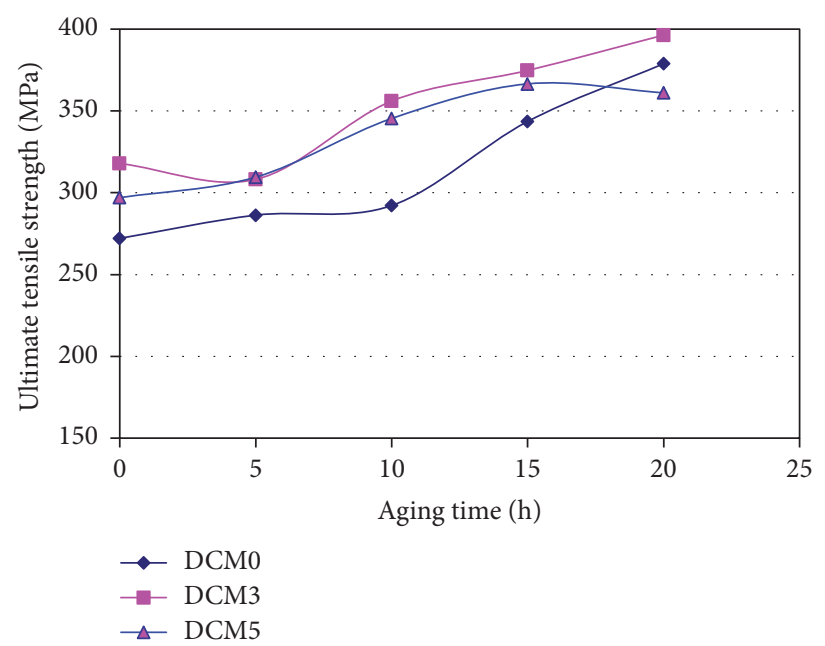

(a)

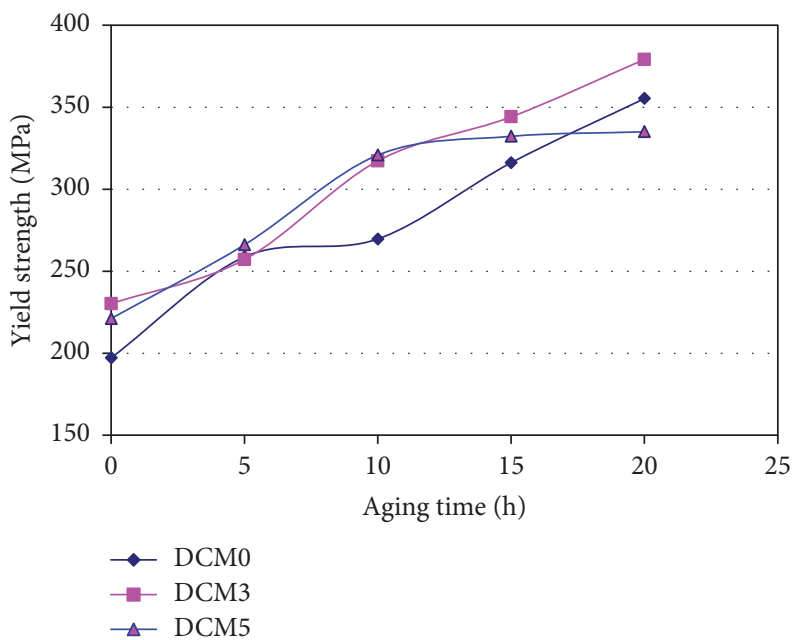

(b)

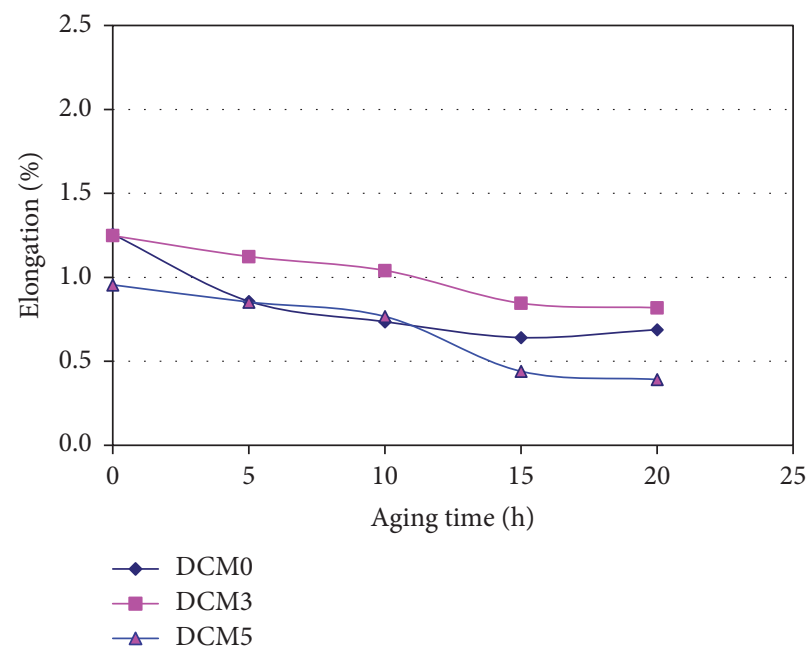

(c)

FIGURE 6: Variation in the alloy tensile properties as a function of aging time at $155^{\circ} \mathrm{C}$ : (a) UTS, (b) YS, and (c) \% El.

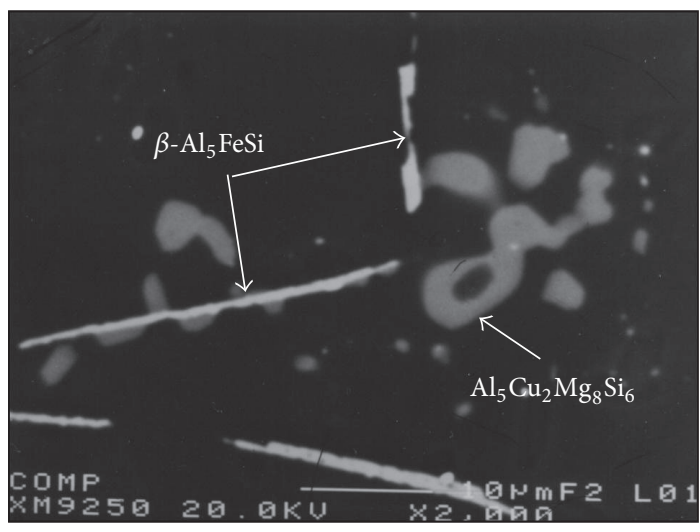

FIGURE 7: Backscattered electron image of DCM5 alloy solutionized at $490^{\circ} \mathrm{C}$.

initiation site followed by homogeneous propagation in the form of concentric circles. Figure 13(b) is an enlarged image of Figure 13(a) revealing the brittleness nature of the studied alloy. Figure 13(c) displays the fracture surface of the same alloy following solution heat treatment at $490^{\circ} \mathrm{C}$ for $8 \mathrm{~h}$ showing rather a ductile fracture with different slip planes and dimple structure. Figure 13(d) reveals the coarsening of the dimple structure when the alloy was aged at $220^{\circ} \mathrm{C}$ for $10 \mathrm{~h}$. In this case the crack was imitated from different directions (black arrows). As mentioned previously, the applied heat treatment causes partial incipient melting that appears in the form of fine porosity.

Figure 14 illustrates the effect of aging condition on the failure mechanism of DCM5 alloy samples. In Figure 14(a) several crack initiation sites can be observed. A high magnification image of Figure 14(a) has been produced in Figure 14(b) revealing the ductile nature of the sample as inferred from the fine dimple network. Figures 14(c) and 14(d) reveal similar observation when the fatigue sample was aged at $220^{\circ} \mathrm{C}$ for $25 \mathrm{~h}$. Due to the higher aging temperature and time the dimple structure is somewhat coarser 


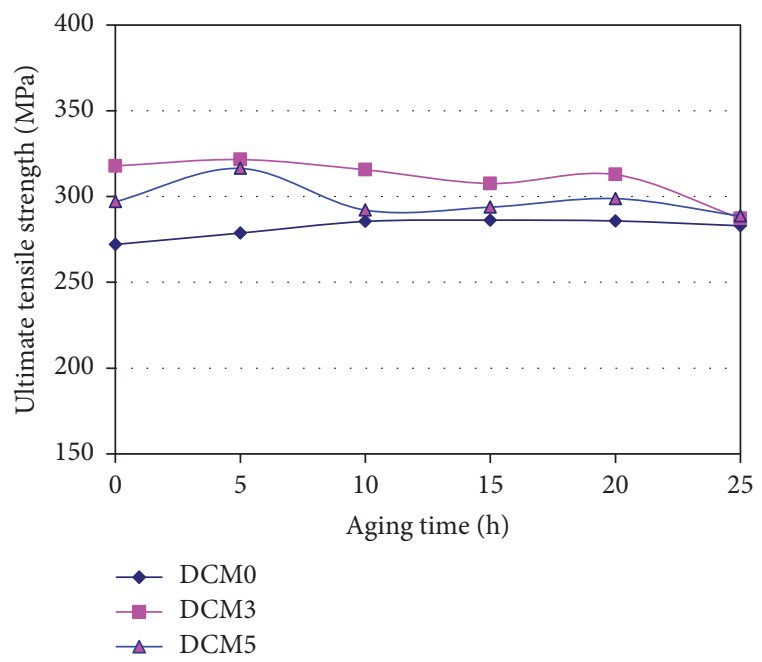

(a)

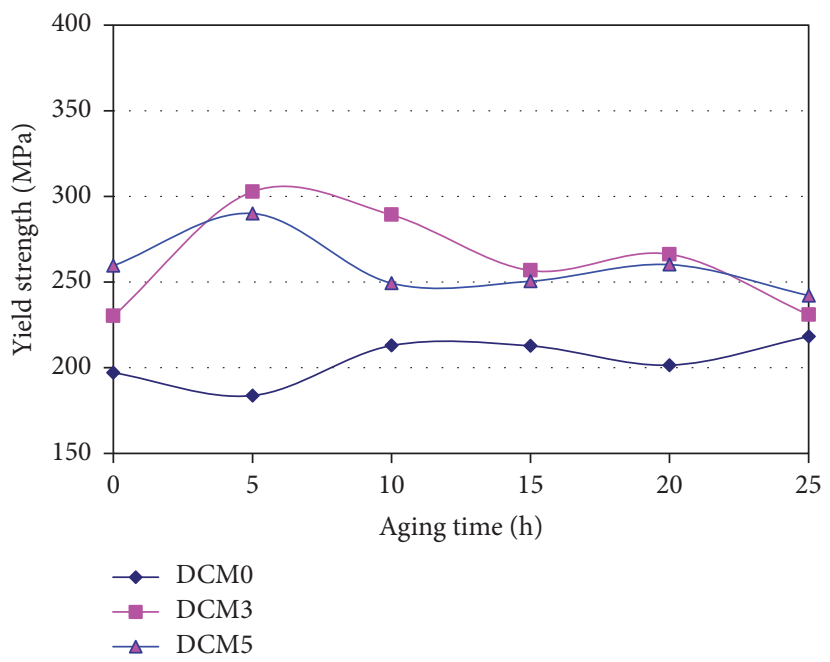

(b)

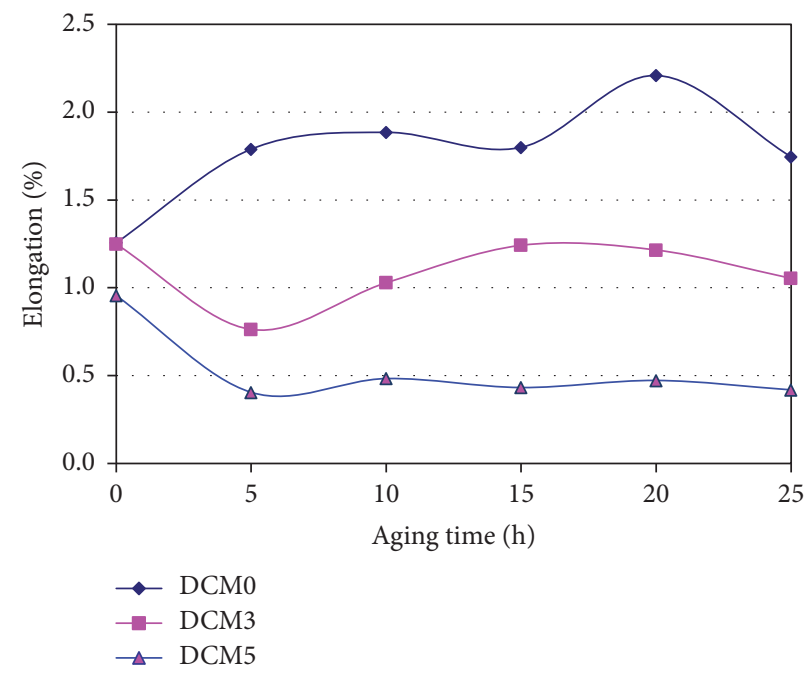

(c)

FIGURE 8: Variation in the alloy tensile properties as a function of aging time at $220^{\circ} \mathrm{C}$ : (a) UTS, (b) YS, and (c) \% El.

in this case than that reported in samples aged at $155^{\circ} \mathrm{C}$ for $20 \mathrm{~h}$. Comparison between Figures 13 and 14 indicates the progress in the size of ductile with the applied heat treatment. Figure 15 is a schematic diagram representing the proposed fracture mechanisms in the presence (Figure 15(a)) or absence (Figure 15(b)) of crack initiation sites.

The effect of casting defects of the fracture of fatigue tested samples of DCM3 alloy is displayed in Figure 16. Figure 16(a) exemplifies the presence of casting defect which is probably caused during opening of the mold while the sample was not fully solidified. Although the size of this imperfection is about $40 \mu \mathrm{m}$ it may act as a crack initiating site. As can be seen the crack propagates in a radial pattern and is associated with the formation of several slip lines marking the number of fatigue cycles. Figure 16(b) represents the crack propagation area of the same sample in Figure 16(a) composed of uniform dimple structure with no porosity typical of ductile failure. Figure 16(c) is the fracture surface of the DCM5 alloy following aging at $220^{\circ} \mathrm{C}$ for $25 \mathrm{~h}$. Although fracture surface is characterized by the presence of fine dimple structure developed by the overaging process, there are two types of defects: fine porosity (white arrows) created by the incipient melting of $\mathrm{Al}_{2} \mathrm{Cu}$ and the complex phase of $\mathrm{Al}_{5} \mathrm{Cu}_{2} \mathrm{Mg}_{8} \mathrm{Si}_{6}$. The large pore observed in the upper corner of Figure 16(c) (black arrow) is mainly due to gas absorption during remelting of the alloy prior to LPDC injection. The presence of such imperfection would lead to premature failure. Another major type of defects that could take place during an LPDC process is the misalignment of the two parts of the mold as shown in Figure 16(d). In spite of the 

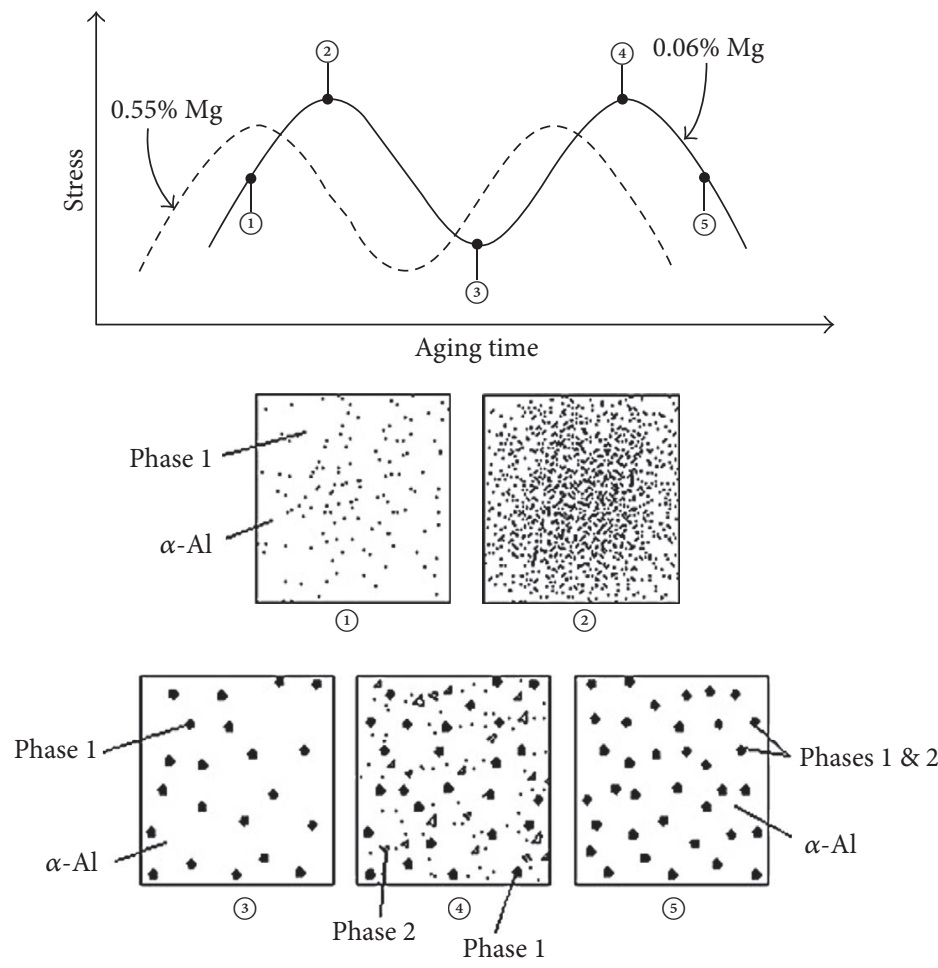

FIGURE 9: Schematic diagrams showing the possible precipitation, dissolution, and coarsening of the age hardening phases during the course of aging.

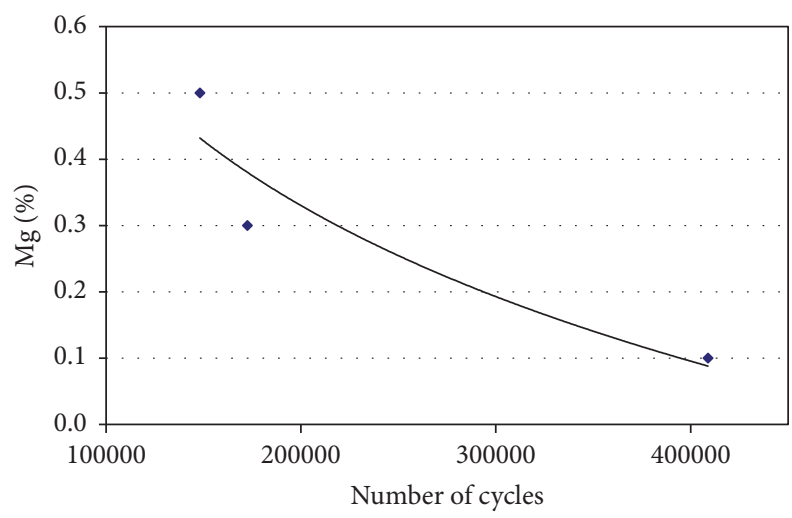

FIGURE 10: Dependence of number of cycles on the Mg content (\%) in the as-cast condition.

fact that this defect is about $50 \mu \mathrm{m}$, it is sufficient to act as a crack site initiator and hence leads to a low number of fatigue cycles.

\section{Conclusions}

Based on the results obtained in the present study, the following conclusions may be drawn:

(1) Application of the LPDC process resulted in ultrafine microstructure.

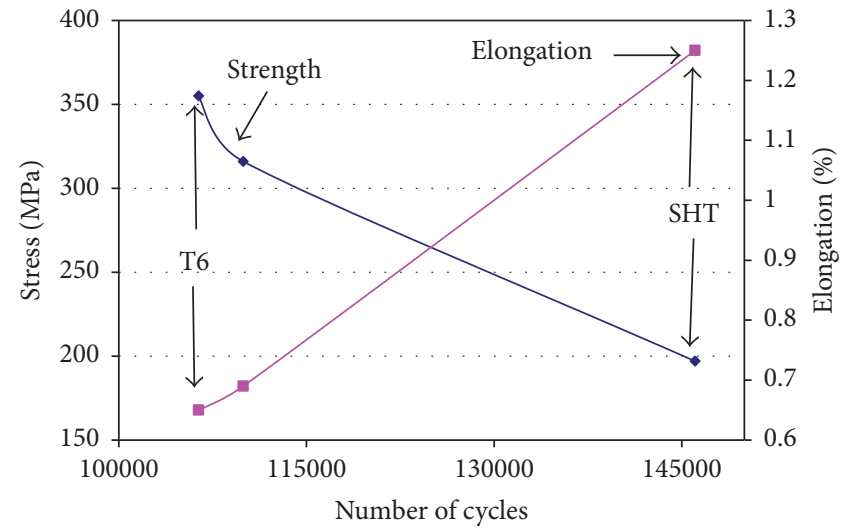

FIGURE 11: Stress-number of cycles (S-N) curve for DCM0 alloys.

(2) Applying high solutionizing temperature to dissolve the maximum amount of $\mathrm{Cu}$ may result in the formation of fine porosity as a result of incipient melting in alloys containing high $\mathrm{Mg}$, for example, $0.55 \%$.

(3) Aging of $\mathrm{Mg}$-containing 380 alloy at $155^{\circ} \mathrm{C}$ is associated with a monotonic increase in the alloy strength with the aging time. Aging at $220^{\circ} \mathrm{C}$, however, revealed two peaks caused by precipitation, dissolution, and coarsening of different phases. 


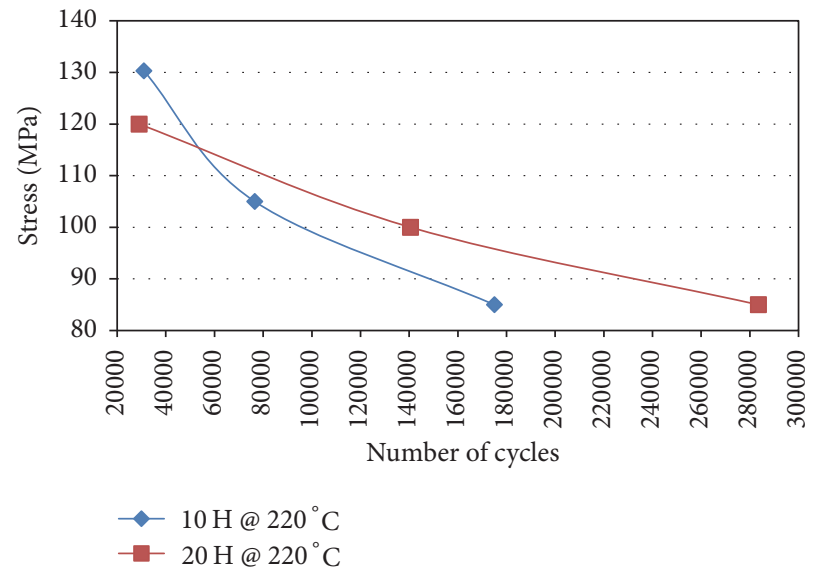

(a)

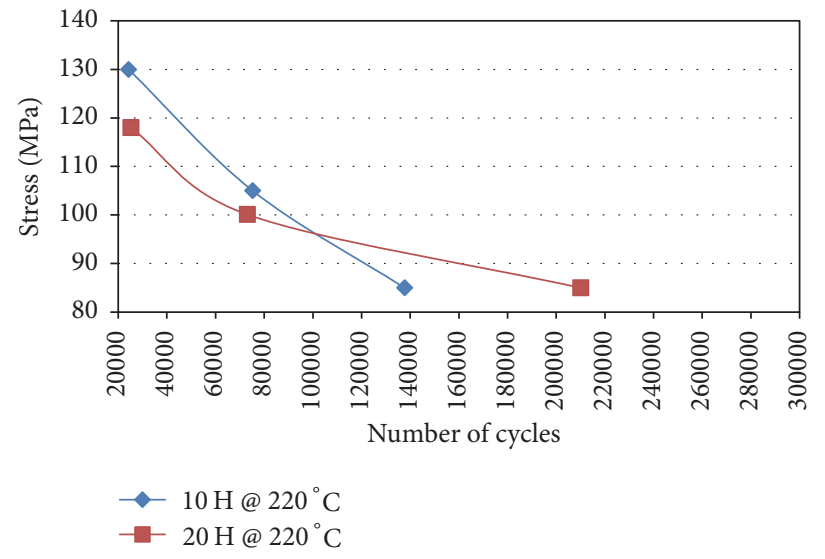

(b)

FIGURE 12: S-N curves for (a) DCM3 alloy and (b) DCM5 alloy.

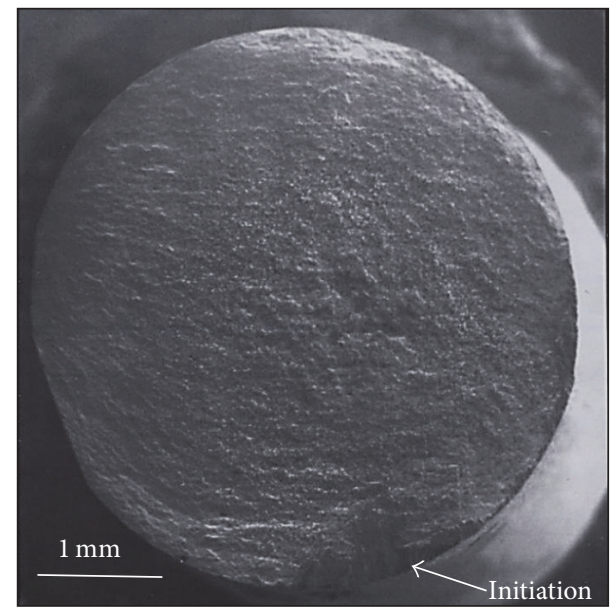

(a)

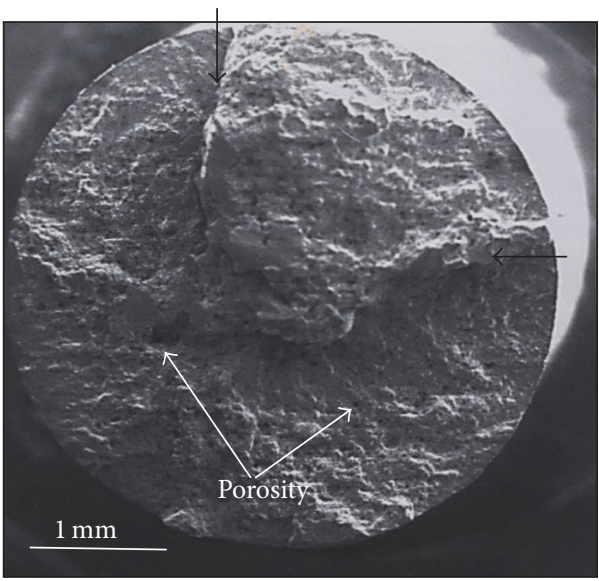

(c)

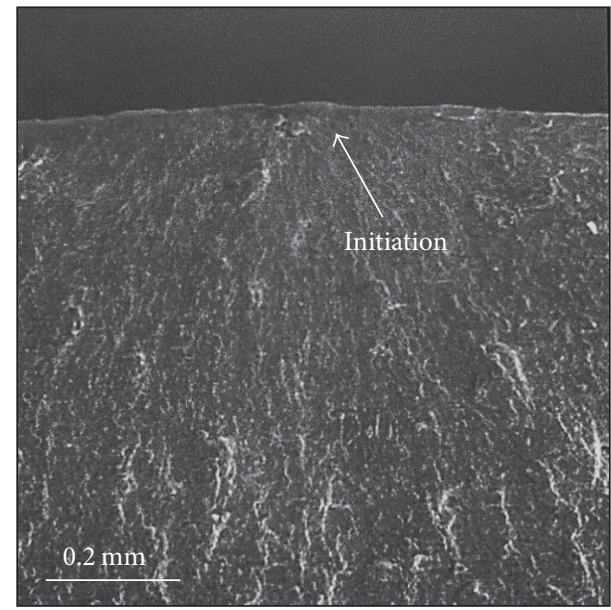

(b)

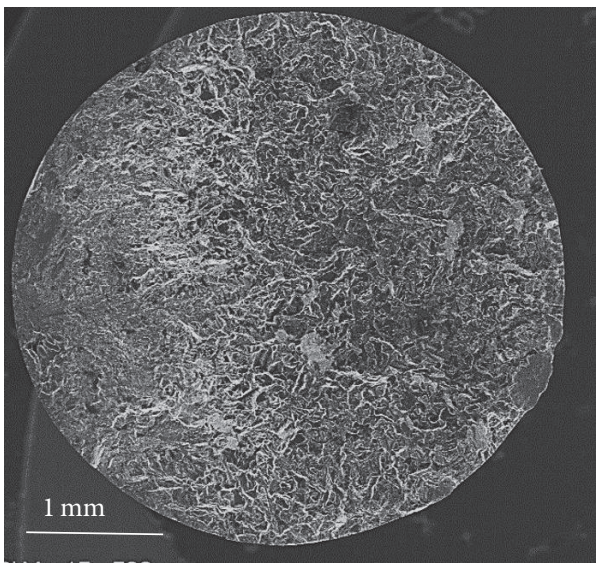

(d)

FIGURE 13: Fracture surface of fatigue samples of DCM3: (a) after solidification, (b) an enlarged image of (a), (c) following solutionizing treatment, and (d) after aging at $220^{\circ} \mathrm{C}$ for $20 \mathrm{~h}$. 


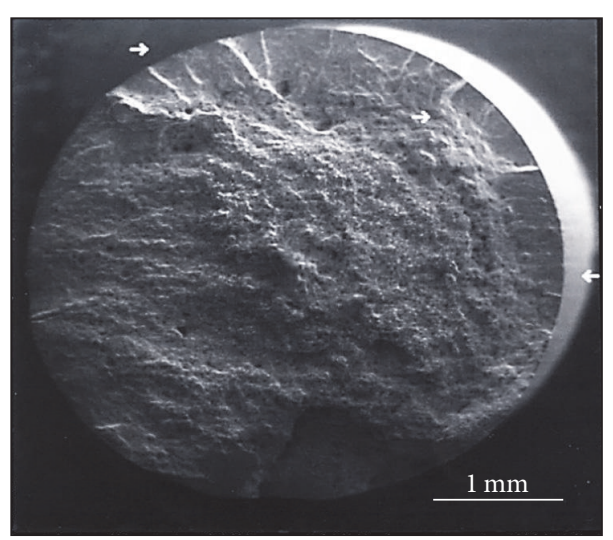

(a)

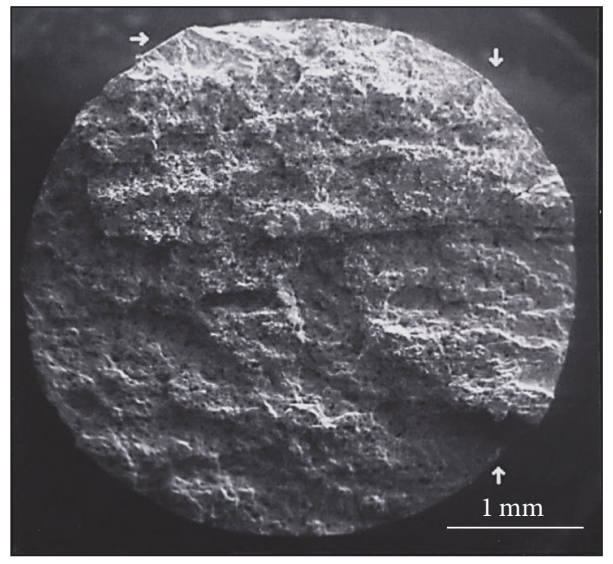

(c)

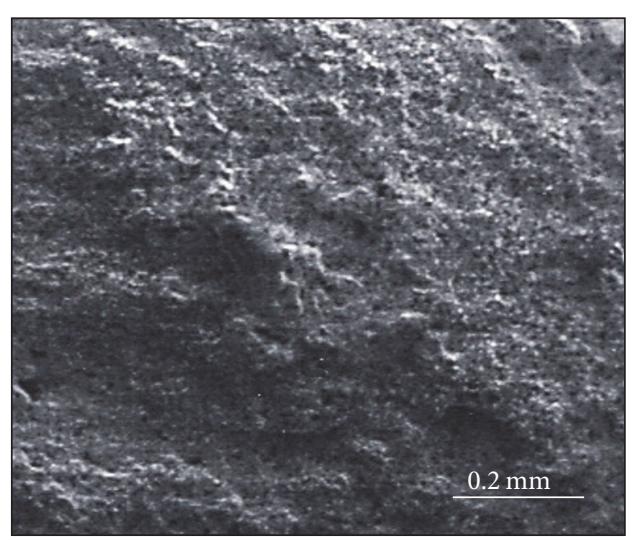

(b)

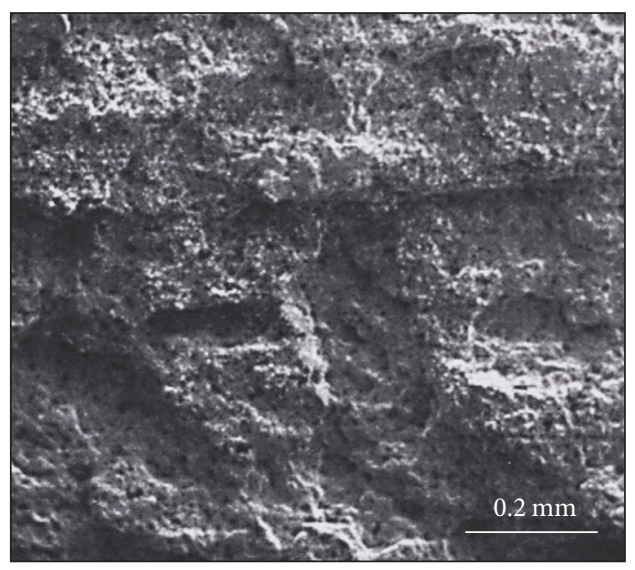

(d)

FIGURE 14: Fracture surface of fatigue DCM5 samples following aging at (a and b) $155^{\circ} \mathrm{C}$ for $20 \mathrm{~h}$ and (c and d) $220^{\circ} \mathrm{C}$ for $25 \mathrm{~h}$. The white arrows in (a) and (c) refer to crack initiation sites.

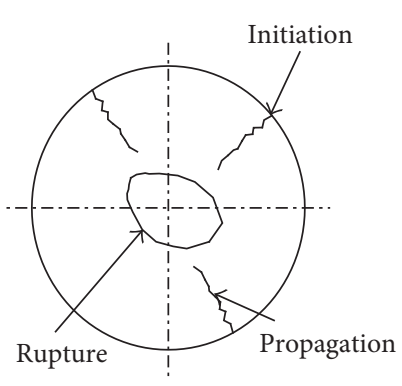

(a)

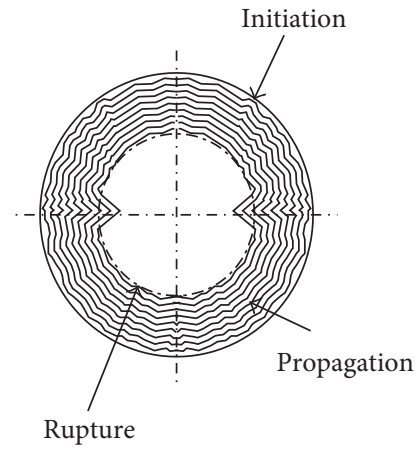

(b)

FIGURE 15: Schematic diagram showing the proposed crack initiation and propagation mechanisms in the present work: (a) several initiation sites and (b) concentric propagation.

(4) Due to the presence of appreciable amount of porosity in the heat treated samples, the applied stresses for the fatigue samples were limited to the elastic region.
(5) When the fatigue sample was aged at $155^{\circ} \mathrm{C}$ for $20 \mathrm{~h}$, the cracks commenced from certain points on the sample surface and propagated towards the alloy centre. 


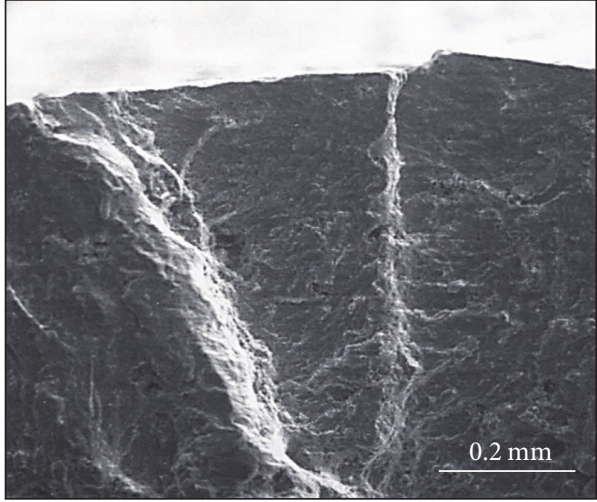

(a)

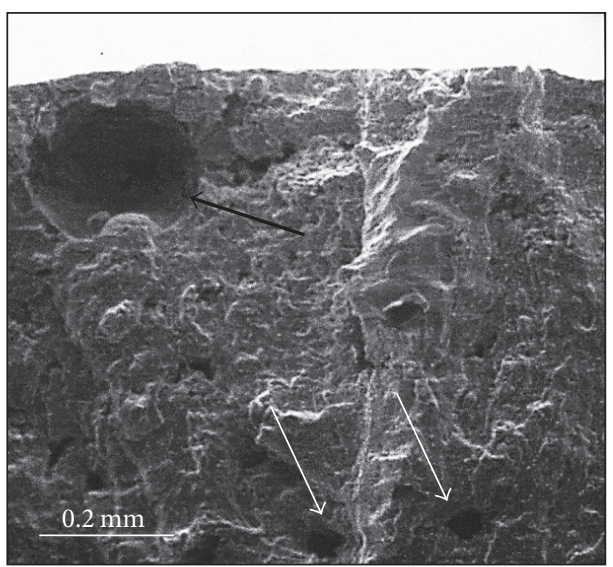

(c)

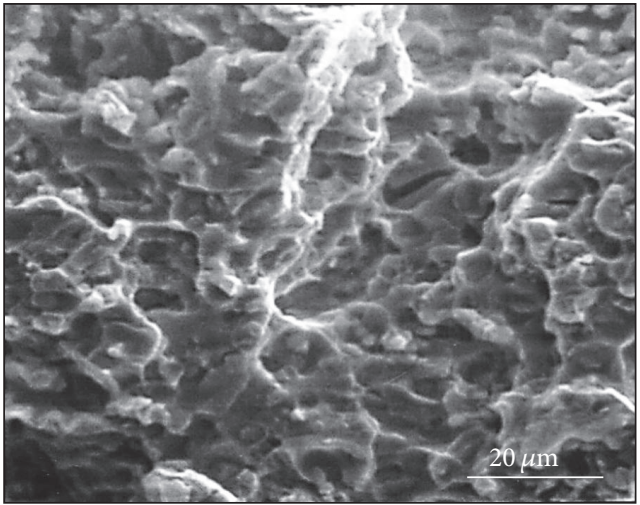

(b)

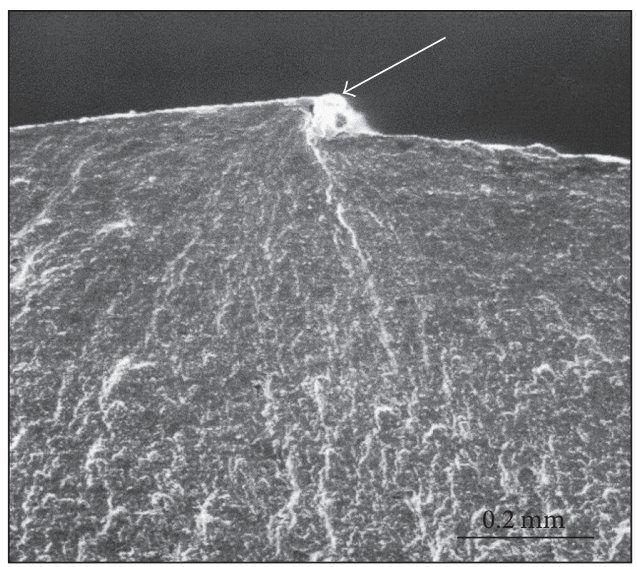

(d)

FIGURE 16: Fracture surfaces of DCM5 fatigue samples: (a, b, and d) after casting and (c) after aging at $220^{\circ} \mathrm{C}$ for $25 \mathrm{~h}$.

(6) When the sample was aged at $220^{\circ} \mathrm{C}$ for $20 \mathrm{~h}$, the cracks were initiated circumferentially followed by propagation towards the centre of the sample up to rupture.

\section{Competing Interests}

The authors declare that they have no competing interests.

\section{Acknowledgments}

The authors would like to thank Amal Samuel for enhancing the quality of the images used in the present article.

\section{References}

[1] F. T. Lee, J. F. Major, and F. H. Samuel, "Effect of silicon particles on the fatigue crack growth characteristics of Al-12 Wt Pct Si0.35 Wt Pct Mg-(0 to 0.02) Wt Pct Sr casting alloys," Metallurgical and Materials Transactions A, vol. 26, no. 6, pp. 1553-1570, 1995.

[2] F. T. Lee, J. F. Major, and F. H. Samuel, "Fracture behaviour of Al12wt.\%Si0.35wt.\% $\mathrm{Mg}(0-0.02)$ wt.\%Sr casting alloys under fatigue testing," Fatigue and Fracture of Engineering Materials and Structures, vol. 18, no. 3, pp. 385-396, 1995.
[3] Q. G. Wang, P. N. Crepeau, J. R. Griffiths, and C. J. Davidson, "The effect of oxide films and porosity on fatigue of cast aluminum alloys," in Shape Casting: The John Campbell Symposium, M. Tiryakioglu and P. N. Crepeau, Eds., pp. 205-214, The Minerals, Metals, \& Materials Society, Warrendale, Pa, USA, 2005.

[4] L. Lasa and J. M. Rodriguez-Ibabe, "Toughness and fatigue behaviour of eutectic and hypereutectic $\mathrm{Al}-\mathrm{Si}-\mathrm{Cu}-\mathrm{Mg}$ alloys produced through lost foam and squeeze casting," Materials Science and Technology, vol. 20, no. 12, pp. 1599-1608, 2004.

[5] H. Mayer, M. Papakyriacou, B. Zettl, and S. E. Stanzl-Tschegg, "Influence of porosity on the fatigue limit of die cast magnesium and aluminium alloys," International Journal of Fatigue, vol. 25, no. 3, pp. 245-256, 2003.

[6] H. R. Ammar, A. M. Samuel, and F. H. Samuel, "Effect of HIPping on the fatigue life of C354-T6 casting alloy," AFS Transactions, vol. 115, pp. 97-104, 2007.

[7] H. R. Ammar, A. M. Samuel, and F. H. Samuel, "Porosity and the fatigue behavior of hypoeutectic and hypereutectic aluminumsilicon casting alloys," International Journal of Fatigue, vol. 30, no. 6, pp. 1024-1035, 2008.

[8] H. R. Ammar, C. Moreau, A. M. Samuel, F. H. Samuel, and H. W. Doty, "Influences of alloying elements, solution treatment time and quenching media on quality indices of 413-type Al-Si casting alloys," Materials Science and Engineering A, vol. 489, no. 1-2, pp. 426-438, 2008. 
[9] H. R. Ammar, A. M. Samuel, and F. H. Samuel, "Effects of surface porosity on the fatigue strength of AE425 and PM390 hypereutectic Al-Si casting alloys at medium and elevated temperatures," Materials Science and Engineering A, vol. 473, no. 1-2, pp. 58-64, 2008.

[10] H. R. Ammar, A. M. Samuel, and F. H. Samuel, "Effect of casting imperfections on the fatigue life of 319-F and A356-T6 Al-Si casting alloys," Materials Science and Engineering A, vol. 473, no. 1-2, pp. 65-75, 2008.

[11] G. K. Sigworth and C. H. Caceres, "Porosity formation in aluminum alloy castings under quasi-directional solidification," International Journal of Cast Metals Research, vol. 9, pp. 331-336, 1997.

[12] X.-S. Jiang, G.-Q. He, B. Liu, S.-J. Fan, and M.-H. Zhu, "Microstructure-based analysis of fatigue behaviour of Al-SiMg alloy," Transactions of Nonferrous Metals Society of China, vol. 21, no. 3, pp. 443-448, 2011.

[13] M. Zamani, Al-Si Cast Alloys Microstructure and Mechanical Properties at Ambient and Elevated Temperature, School of Engineering, Jönköping University, 2015.

[14] R. B. Gundlach, B. Ross, A. Hetke, S. Valtierra, and J. F. Mojica, "Thermal fatigue resistance of hypoeutectic aluminum-silicon casting alloys," AFS Transactions, vol. 102, pp. 205-223, 1994.

[15] I. Boromei, L. Ceschini, A. Morril, G. Nicoletto, and E. Riva, "Influence of the solidification microstructure and porosity on the fatigue strength of Al-Si-Mg casting alloys," Metallurgical Science and Technology, vol. 28, pp. 18-24, 2010.

[16] M. F. Ibrahim, S. A. Alkahtani, K. A. Abuhasel, and F. H. Samuel, "Effect of intermetallics on the microstructure and tensile properties of aluminum based alloys: role of $\mathrm{Sr}, \mathrm{Mg}$ and $\mathrm{Be}$ addition," Materials and Design, vol. 86, pp. 30-40, 2015.

[17] L. Bäckerud, G. Chai, and J. Tamminen, Solidification Characteristics of Aluminium Alloys, Volume 2: Foundry Alloys, AFS/Skanaluminium, Des Plaines, Ill, USA, 1990.

[18] E. Samuel, A. M. Samuel, H. W. Doty, S. Valtierra, and F. H. Samuel, "Intermetallic phases in Al-Si based cast alloys: new perspective," International Journal of Cast Metals Research, vol. 27, no. 2, pp. 107-114, 2014.

[19] R. N. Lumley, R. G. O'Donnell, D. R. Gunasegaram, and M. Givord, "Heat treatment of high-pressure die castings," Metallurgical and Materials Transactions A, vol. 38, no. 10, pp. 25642574, 2007.

[20] J. Osten, B. Milkereit, C. Schick, and O. Kessler, "Dissolution and precipitation behaviour during continuous heating of Al$\mathrm{Mg}-\mathrm{Si}$ alloys in a wide range of heating rates," Materials, vol. 8 , no. 5, pp. 2830-2848, 2015.

[21] D. Apelian, S. Shivkumar, and G. Sigworth, "Fundamental aspects of heat treatment of cast Al-Si-Mg alloys," AFS Transactions, vol. 97, pp. 727-742, 1989.

[22] F. H. Samuel, "Incipient melting of $\mathrm{Al}_{5} \mathrm{Mg}_{8} \mathrm{Si}_{6} \mathrm{Cu}_{2}$ and $\mathrm{Al}_{2} \mathrm{Cu}$ intermetallics in unmodified and strontium-modified Al-Si$\mathrm{Cu}-\mathrm{Mg}$ (319) alloys during solution heat treatment," Journal of Materials Science, vol. 33, no. 9, pp. 2283-2297, 1998.

[23] A. M. A. Mohamed, F. H. Samuel, and S. A. Alkahtani, "Assessment of the effect of $\mathrm{Mg}$ addition on the solidification behavior of Al-Si-Cu cast alloys," AFS Transactions, vol. 120, pp. 85-96, 2012.

[24] A. M. A. Mohamed and F. H. Samuel, "A review on the heat treatment of Al-Si-Cu/Mg casting alloys," in Heat TreatmentConventional and Novel Applications, chapter 4, pp. 55-72, InTech, 2012.
[25] N. R. Andrade, J. E. Gruzleski, F. H. Samuel, S. Valtierra, and H. W. Doty, "Age-hardening precipitates in cast 319 aluminum alloys," in Proceedings of the International Symposium on Aluminium: From Raw Materials to Applications, 45th Annual Conference of Metallurgists of CIM (COM '06), pp. 104-114, Montreal, Canada, 2006.

[26] N. R. Andrade, J. E. Gruzleski, F. H. Samuel, S. Valtierra, and H. W. Doty, "Effect of Mg and Sr additions in 319-type aluminum casting alloys," in Proceedings of the International Symposium on Light Metals, pp. 205-218, Calgary, Canada, August 2005.

[27] N. R. Andrade, J. E. Gruzleski, and F. H. Samuel, "Aging behavior of 319 type aluminum casting alloys," in Proceedings of the 26th International Congress on Metallurgy and Materials, Institute Tecnologico de Saltillo, Saltillo, Mexico, 2004.

[28] N. R. Andrade, F. Paray, J. E. Gruzleski, and F. H. Samuel, "Aging effects in 319 alloys," in Light Metals and Metal Matrix Composites, D. Gallienne and R. Ghomashchi, Eds., pp. 111-125, 2004.

[29] H. J. Le Boiteux, La Fatigue dans les Matériaux, Édiscience, McGraw-Hill, Paris, France, 1973. 

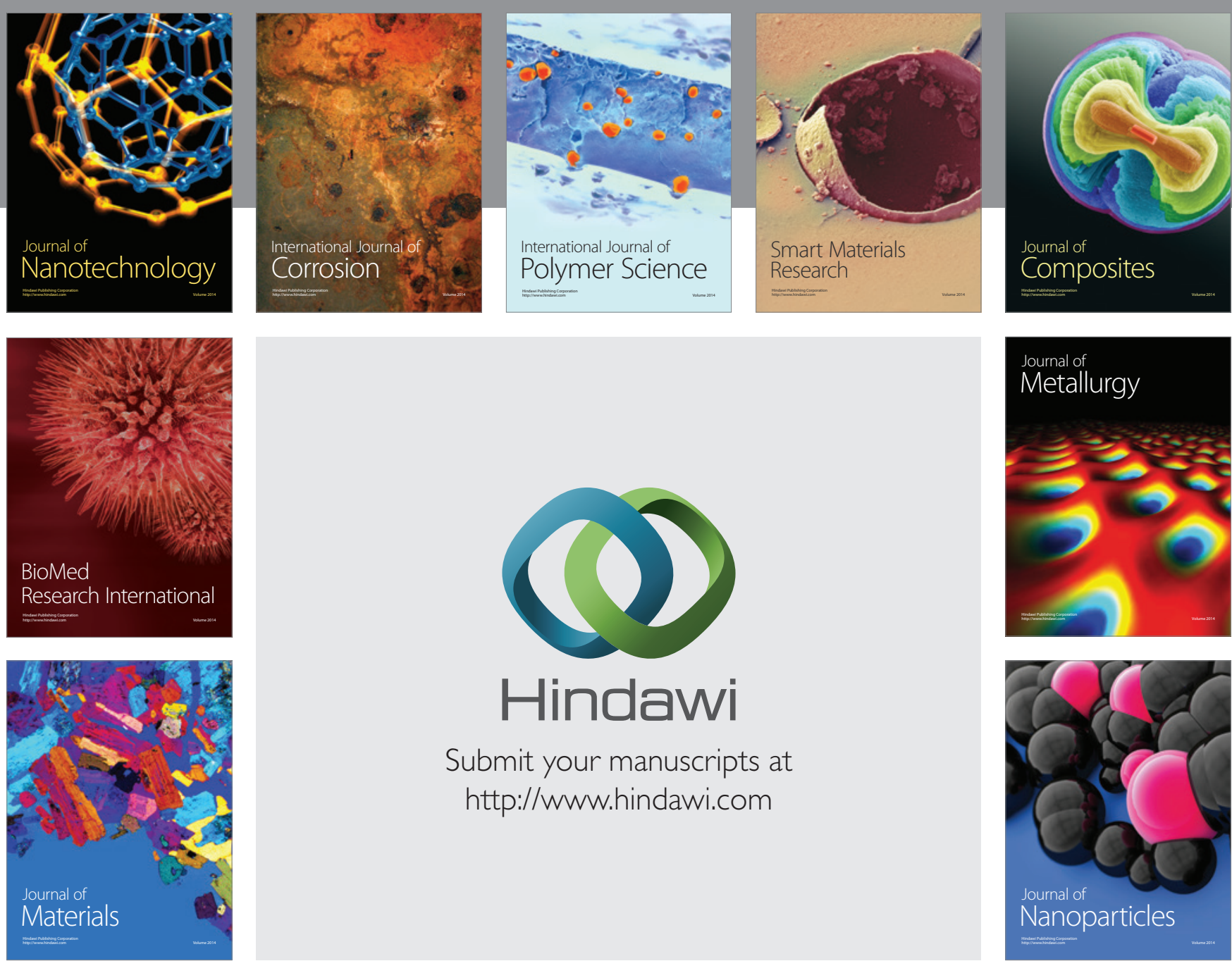

\section{Hindawi}

Submit your manuscripts at

http://www.hindawi.com

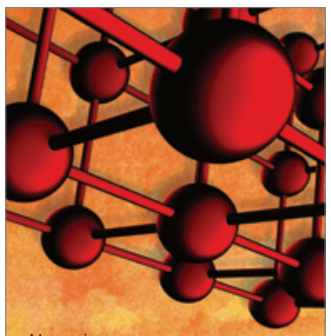

Materials Science and Engineering
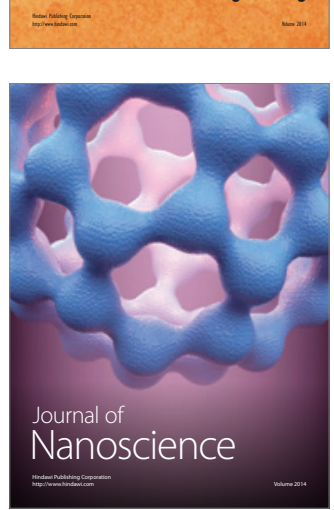
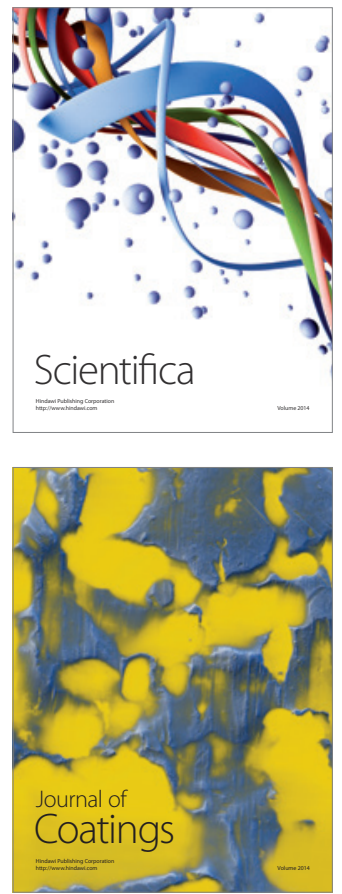
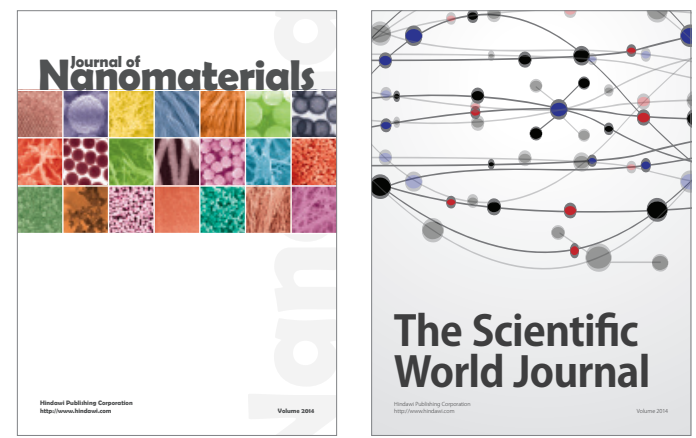

The Scientific World Journal
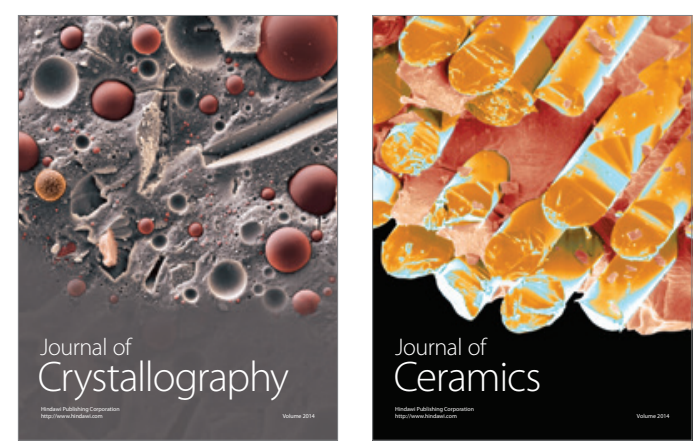
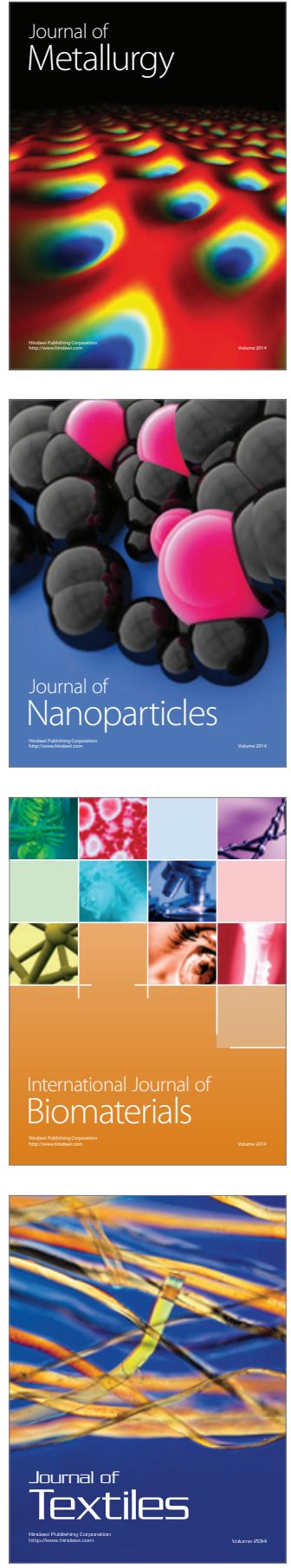